\title{
A Lack of Serotonin IB Autoreceptors Results in Decreased Anxiety and Depression-Related Behaviors
}

\author{
Katherine M Nautiyal ${ }^{1,2}$, Laurent Tritschler ${ }^{3}$, Susanne E Ahmari ${ }^{4}$, Denis J David ${ }^{3}$, Alain M Gardier ${ }^{3}$ and \\ René Hen*,I,2,5 \\ 'Department of Psychiatry, Columbia University, New York, NY, USA; ${ }^{2}$ Division of Integrative Neuroscience, The New York State Psychiatric \\ Institute, New York, NY, USA; ${ }^{3}$ Université Paris-Saclay, University Paris-Sud, Faculté de Pharmacie, CESP, INSERM UMRS I I 78, Chatenay-Malabry, \\ France; ${ }^{4}$ Department of Psychiatry, Translational Neuroscience Program, Center for Neuroscience Program, Center for the Neural Basis of \\ Cognition, University of Pittsburgh, Pittsburgh, PA, USA; ${ }^{5}$ Department of Neuroscience, Columbia University, New York, NY, USA
}

\begin{abstract}
The effects of serotonin (5-HT) on anxiety and depression are mediated by a number of 5-HT receptors, including autoreceptors that act to inhibit 5-HT release. While the majority of anxiety and depression-related research has focused on the 5- $\mathrm{HT}_{\text {IA }}$ receptor, the 5-HTIB receptor has a lesser known role in modulating emotional behavior. 5-HTIB receptors are inhibitory GPCRs located on the presynaptic terminal of both serotonin and non-serotonin neurons, where they act to inhibit neurotransmitter release. The autoreceptor population located on the axon terminals of 5-HT neurons is a difficult population to study due to their diffuse localization throughout the brain that overlaps with $5-\mathrm{HT}_{\mathrm{IB}}$ heteroreceptors (receptors located on non-serotonergic neurons). In order to study the contribution of 5- $\mathrm{HT}$ IB autoreceptors to anxiety and depression-related behaviors, we developed a genetic mouse model that allows for selective ablation of 5- $\mathrm{HT}_{\text {IB }}$ autoreceptors. Mice lacking 5- $\mathrm{HT}_{\text {IB }}$ autoreceptors displayed the expected increases in extracellular serotonin levels in the ventral hippocampus following administration of a selective serotonin reuptake inhibitor. In behavioral studies, they displayed decreased anxietylike behavior in the open field and antidepressant-like effects in the forced swim and sucrose preference tests. These results suggest that strategies aimed at blocking 5-HT IB autoreceptors may be useful for the treatment of anxiety and depression.

Neuropsychopharmacology (2016) 4I, 294I-2950; doi:I0.1038/npp.2016.109; published online 20 July 2016
\end{abstract}

\section{INTRODUCTION}

Dysregulation of serotonin signaling is present in a number of mood-related psychiatric disorders, including major depressive disorder (Lucki, 1998; Ressler and Nemeroff, 2000). Serotonin (5-HT) autoreceptors play a major role in regulating serotonergic tone and modulating the response to antidepressant pharmacotherapies (Richardson-Jones et al, 2010; Stamford et al, 2000). While the majority of research has focused on serotonin $1 \mathrm{~A}\left(5-\mathrm{HT}_{1 \mathrm{~A}}\right)$ autoreceptors, evidence also points to serotonin $1 \mathrm{~B}\left(5-\mathrm{HT}_{1 \mathrm{~B}}\right)$ autoreceptors as a major regulator of serotonin transmission and emotionality (Donaldson et al, 2014; McDevitt and Neumaier, 2011; Richardson-Jones et al, 2010). In rodent models, activation of $5-\mathrm{HT}_{1 \mathrm{~B}}$ receptors decreases serotonin levels through effects on release, synthesis, and reuptake (Hagan et al, 2012; Hjorth et al, 1995; Trillat et al, 1997). Additionally, 5- $\mathrm{HT}_{1 \mathrm{~B}} \mathrm{R}$ knockout mice have increased levels of 5-HT, compared with wild-type mice, following administration of a selective serotonin reuptake inhibitor (SSRI)

*Correspondence: Professor R Hen, Center for Neurobiology and Behavior, Columbia University, 722 W I68th St, P.I. Annex 73I, I05I Riverside Drive, Unit 87, New York, NY 10032-2695, USA, Tel: + I 646 774 7108, Fax: + 646774 7102, E-mail: rh95@columbia.edu Received 20 October 2015; revised 17 June 2016; accepted 21 June 2016; accepted article preview online 29 June 2016
(Knobelman et al, 2001; Malagie et al, 2001). Behaviorally, an absence of all $5-\mathrm{HT}_{1 \mathrm{~B}} \mathrm{Rs}$ in mice results in decreased depressive behaviors (Bechtholt et al, 2008; Jones and Lucki, 2005; Mayorga et al, 2001). However, these studies were not able to directly distinguish the contribution of autoreceptors from the rest of $5-\mathrm{HT}_{1 \mathrm{~B}} \mathrm{Rs}$.

5- $\mathrm{HT}_{1 \mathrm{~B}} \mathrm{Rs}$ are inhibitory Gi/Go coupled GPCRs expressed on axon terminals, which act to inhibit terminal neurotransmitter release (Boschert et al, 1994; Ghavami et al, 1999; Mizutani et al, 2006). In addition to the population of 5$\mathrm{HT}_{1 \mathrm{~B}}$ autoreceptors located on serotonin neurons, 5- $\mathrm{HT}_{1 \mathrm{~B}}$ heteroreceptors are located on the presynaptic terminals of non-serotonergic neurons, including GABA, ACh, and glutamate neurons (Sari, 2004). These distinct populations can act in different or sometimes opposing roles to modulate behavior. Additionally, $5-\mathrm{HT}_{1 \mathrm{~B}} \mathrm{Rs}$ are located throughout the brain and overlapping localization of hetero- and autoreceptors makes pharmacological manipulation an ineffective tool to isolate the two populations.

There is preclinical evidence that supports the role of $5-\mathrm{HT}_{1 \mathrm{~B}}$ autoreceptors in the modulation of anxiety and depressive behaviors. Viral overexpression of $5-\mathrm{HT}_{1 \mathrm{~B}} \mathrm{R}$ in the raphe results in increased anxiety behavior following stressors (Clark et al, 2002), and $5-\mathrm{HT}_{1 \mathrm{~B}} \mathrm{mRNA}$ in the raphe is elevated in models of depression, such as learned helplessness, and following stress (Neumaier et al, 
1997, 2002). Additionally, reductions in $5-\mathrm{HT}_{1 \mathrm{~B}}$ autoreceptors are associated with antidepressant treatment. Specifically, following SSRI treatment, $5-\mathrm{HT}_{1 \mathrm{~B}} \mathrm{R}$ mRNA is reduced in the raphe but not in the hippocampus, cortex, or striatum, suggesting that this effect is specific to autoreceptors (Anthony et al, 2000; Neumaier et al, 1996). Other studies also show desensitization of $5-\mathrm{HT}_{1 \mathrm{~B}}$ autoreceptors following SSRI treatment (Davidson and Stamford, 2000). Furthermore, in humans a recent PET study showed that following successful cognitive behavioral therapy treatment for depression, $5-\mathrm{HT}_{1 \mathrm{~B}} \mathrm{R}$ binding is reduced in the brain stem region that contains the raphe (Tiger et al, 2014). Taken together, these data suggest a role for $5-\mathrm{HT}_{1 \mathrm{~B}}$ autoreceptors in depression-related behaviors.

The current studies were designed to test if a reduction of $5-\mathrm{HT}_{1 \mathrm{~B}}$ autoreceptors was sufficient to produce an antidepressant-like effect. To address this question, we used a genetic approach to selectively ablate $5-\mathrm{HT}_{1 \mathrm{~B}} \mathrm{Rs}$ from serotonin cells in mice, and measured the resulting effect on anxiety and depressive behaviors. We used a mouse in which a floxed tetracycline operator (tetO) $-5-\mathrm{HT}_{1 \mathrm{~B}} \mathrm{cDNA}$ cassette was inserted in place of the endogenous coding region of htr $1 \mathrm{~b}$ to generate $\mathrm{Htr} 1 \mathrm{~b}^{\text {tetO/tetO }}$ mice (referred to as floxed tetO1B) as previously described (Nautiyal et al, 2015). Crossing the floxed tetO1B mouse to a transgenic mouse expressing Cre recombinase under the control of the Pet-1 promotor (Scott et al, 2005) allowed selective knockout of $5-\mathrm{HT}_{1 \mathrm{~B}} \mathrm{R}$ autoreceptors. Our results show that mice that lack $5-\mathrm{HT}_{1 \mathrm{~B}}$ autoreceptors have increased levels of serotonin in the hippocampus in response to an SSRI, and show reduced depressive and anxiety-like behavior.

\section{MATERIALS AND METHODS}

\section{Animals}

Mice were bred in the Department of Comparative Medicine animal facility at the New York State Psychiatric Institute (NYSPI) at the Columbia University Medical Center. The floxed tetO1B mouse model was used to generate groups of mice with alterations in $5-\mathrm{HT}_{1 \mathrm{~B}} \mathrm{R}$ expression (Nautiyal et al, 2015). Autoreceptor 5- $\mathrm{HT}_{1 \mathrm{~B}} \mathrm{R}$ knockout was achieved by crossing tet $\mathrm{O} 1 \mathrm{~B}$ mice to mice-expressing Cre recombinase (Cre) or tetracycline-controlled transcriptional silencer (tTS) under the control of the Pet-1 promoter, affecting serotonergic cells (Richardson-Jones et al, 2010; Scott et al, 2005). All mouse lines were maintained on a mixed C57BL/6-129/ $\mathrm{Sv}$ background. Mice were bred in-house in the NYSPI barrier facility by pairing a homozygous tetO1B female with a homozygous tetO1B male that was also hemizygous for the ePet-Cre or Pet-tTS transgenes. This breeding strategy allowed for littermate ePet-Cre-/-::tetO1B+/+ (referred to as ePet-Cre -) mice to serve as controls for the experimental group of ePet-Cre+l - :tetO1B $+/+$ (referred to as ePet-Cre+). All Pet-tTS mice were maintained in the absence of doxycycline throughout life which leads to a developmental knockdown with adult rescue, possibly due to reduced Pet-1 expression during adulthood (RichardsonJones et al, 2010; and see Figure 5).

All mice were males between 12 and 18 weeks of age during testing. $N=17$ ePet-Cre - and $N=10$ ePet-Cre+ mice were run in the open field test followed 7 days later by the elevated plus maze. Subsequently, these mice plus additional naïve mice $(N=17$ ePet-Cre - and $N=17$ ePet-Cre+ $)$ were run in the forced swim test 1 to 3 weeks later. Of these added mice, $N=8$ ePet-Cre - and $N=8$ ePet-Cre+ mice were randomly chosen and tested in a conditioned fear experiment 7 days following the forced swim test. A naïve cohort of $N=11$ ePet-Cre - and $N=9$ ePet-Cre+ mice was used for the sucrose preference experiment. $N=16$ Pet-tTS - and $N=15$ Pet-tTS + mice were run in the open field test, then the forced swim test 7 days later (except for one Pet-tTS mouse that was lost to attrition before being tested in the forced swim test). A separate group of mice was used for microdialysis studies $(N=8$ ePet-Cre - and $N=9$ ePetCre+). Additional groups of mice were also used for autoradiography and in situ hybridization characterization $(N=4$ /group).

Mice were group-housed 3-5 per cage following weaning at postnatal day $(\mathrm{PN}) 21$, in plastic shoebox cages (Allentown Caging; $18 \mathrm{~cm} \times 30 \mathrm{~cm} \times 13 \mathrm{~cm}$ ) with Bed-o'Cobs bedding (Andersons, Maumee, $\mathrm{OH}$ ) in ventilated racks. Food (Prolab Isopro RMH 3000, PMI Nutrition, St Louis, MO) and water were provided ad libitum except during sucrose preference experiments as described below. Animals were maintained on a $12 \mathrm{~h}: 12 \mathrm{~h}$ light-dark cycle and all behavioral testing was conducted during the light cycle. All animal care and testing was approved by the NYSPI Institutional Animal Use and Care Committee and was in accordance with the NIH's Guide for the Care and Use of Laboratory Animals. All experiments, with the exception of microdialysis studies, were carried out in the Department of Comparative Medicine Facility at NSYPI. Microdialysis studies were performed at the Faculté de Pharmacie, Université ParisSud, Châtenay-Malabry, France, in compliance with the protocols approved by the Institutional Animal Care and Use Committee (Council directive \# 87-848, 19 October 1987, Ministère de l'Agriculture et de la Forêt, Service Vétérinaire de la Santé et de la Protection Animale, permission \# 92-196 to AMG).

\section{Tissue Processing}

Brains were extracted from ePet-Cre+ or Pet-tTS+ mice and littermate controls and frozen immediately on crushed dry ice and maintained at $-80^{\circ} \mathrm{C}$ until sectioned using a cryostat (CM3050 S; Leica Biosystems, Wetzlar, Germany). Coronal brain sections, cut at $20 \mu \mathrm{m}$ for adult tissue and $25 \mu \mathrm{m}$ for PN7 tissue, were thaw-mounted on Superfrost slides (Fisher, Fair Lawn, NJ), and maintained at $-80^{\circ} \mathrm{C}$ until processing for receptor autoradiography or in situ hybridization.

Autoradiography for $5-\mathrm{HT}_{1 \mathrm{~B}}$ and $5-\mathrm{HT}_{1 \mathrm{~A}}$ receptors and the serotonin transporter (SERT) was performed on every sixth section throughout the brain (Saudou et al, 1994). For $5-\mathrm{HT}_{1 \mathrm{~B}}$, sections were incubated in $70 \mathrm{pM}$ of $\left[{ }^{125} \mathrm{I}\right]-$ cyanopindolol $(10 \mu \mathrm{l} / 10 \mathrm{ml}$ buffer; Perkin Elmer, Waltham, MA), $3 \mu \mathrm{M}$ isoproterenol, $100 \mathrm{nM} 8-\mathrm{OH}-\mathrm{DPAT}, 0.3 \% \mathrm{BSA}$, $0.01 \%$ ascorbic acid, and $10 \mu \mathrm{M}$ pargyline (Sigma-Aldrich, St Louis, MO) for $2 \mathrm{~h}$. For $5-\mathrm{HT}_{1 \mathrm{~A}}$, sections were incubated in 4 - $\left(2^{\prime}\right.$-methopxyphenyl $)-1-\left[2^{\prime}-\left(n-2^{\prime \prime}\right.\right.$-pyridinyl $)-\mathrm{p}-\left[{ }^{125} \mathrm{I}\right]$ iodobenzamido] ethylpiperazine ([ $\left.\left.{ }^{125}\right] \mathrm{I}-\mathrm{MPPI}\right)$ for $1 \mathrm{~h}$. For SERT, sections were incubated in $50 \mathrm{pM}$ of $\left[{ }^{125} \mathrm{I}\right]$-RTI55 with $100 \mu \mathrm{M}$ nomifensine for $1 \mathrm{~h}$, with nonspecific binding determined with $1 \mu \mathrm{M}$ of fluoxetine. Slides were then 
washed, dried, and exposed to BioMax MR film (Kodak, Rochester, NY), and developed using an X-omat automated developer (Kodak). Films were digitized at a resolution of 1200 dpi using an Epson 3200 Photo Scanner, and signal intensity was measured using NIH Image 1.62. Levels of $5-\mathrm{HT}_{1 \mathrm{~B}} \mathrm{R}$ binding were determined by measuring intensity of the region of interest and subtracting a 'background' level from a nearby region in the same section that lacked specific binding. Each region of interest was sampled at least four times and the average intensity was used. Measurements were only used if the intensity was on the linear portion of the standard curve obtained from an ARC146-F ${ }^{14} \mathrm{C}$ standard (ARC, St Louis, MO).

In situ hybridization for $5-\mathrm{HT}_{1 \mathrm{~B}}$ mRNA was performed based on the Allen Brain Atlas protocol using a digoxigenin (DIG)-labeled htr1b cRNA probe (Tanaka et al, 2012), as previously described (Nautiyal et al, 2015). Briefly, sections were fixed, washed, and treated with $0.2 \mathrm{M} \mathrm{HCl}$ and Proteinase K $(40 \mu \mathrm{g} / \mathrm{ml}$ for adult tissue and $10 \mu \mathrm{g} / \mathrm{ml}$ for PN7 tissue; Roche, Basel, Switzerland) before a second fixation, acetylation, and prehybridization. Hybridization was carried out with a DIG-labeled $h t r 1 b$ probe (labeled using a probe-labeling kit; Roche) for $20 \mathrm{~h}$ at $65^{\circ} \mathrm{C}$. The probe was visualized using anti-DIG phosphataseconjugated antibody (at 1:5000 dilution; Roche) and nitroblue tetrazolium chloride/5-bromo-4-chloro-3-indolylphosphate p-toluidine salt (NBT/BCIP) color substrate (Roche). Staining was visualized on a Zeiss AxioVert200 microscope (Oberkochen, Germany), and images were acquired using an attached Q-Imaging camera and associated QCapture Sofware (Surrey, Canada).

\section{In Vivo Microdialysis}

Mice were anesthetized (chlorale hydrate $400 \mathrm{mg} / \mathrm{kg}$ i.p.) and implanted with concentric microdialysis probes made of cuprophan fibers (active length $2 \mathrm{~mm}$, outer diameter $0.3 \mathrm{~mm}$ ) located in the ventral hippocampus (stereotaxic coordinates AP: $-2.8 \mathrm{~mm}, \mathrm{LL}: \pm 3.0 \mathrm{~mm}, \mathrm{DV}:-4.0 \mathrm{~mm}$, according to Paxinos and Franklin (2001)). Animals were allowed to recover from the surgery overnight. The next day, the probes were continuously perfused with artificial cerebrospinal fluid (composition in mM: $\mathrm{NaCl} 147, \mathrm{KCl}$ 3.5, $\mathrm{CaCl}_{2}$ 1.26, $\mathrm{MgCl}_{2}$ 1.2, $\mathrm{NaHCO}_{3} 25, \mathrm{NaH}_{2} \mathrm{PO}_{4} 1.0, \mathrm{pH}$ $7.4 \pm 0.2$ ) at a flow rate of $1.5 \mu \mathrm{l} / \mathrm{min}$ using a CMA/100 pump (Carnegie Medicin, Stockholm, Sweden) as previously described (Trillat et al, 1997). The animals were awake and freely moving in their cage during the microdialysis protocol. Samples were collected from the ventral hippocampus every $15 \mathrm{~min}$, for $60 \mathrm{~min}$ before (to determine the basal values) and after an injection of escitalopram ( $5 \mathrm{mg} / \mathrm{kg}$ i.p.) (Nguyen et al, 2013), and for another $60 \mathrm{~min}$ following GR 127935, 2' methyl-4'-(5-methyl-[1,2,4] oxadiazol-3-yl)-biphenyl-4-carboxylic acid,administration (5 mg/kg s.c.) (Gardier et al, 2003; Malagie et al, 2001). Samples were analyzed for 5-HT levels using HPLC (column Ultremex $3 \mu \mathrm{m} \mathrm{C18,}$ $75 \times 4.60 \mathrm{~mm}$, particle size $3 \mu \mathrm{m}$; Phenomenex, Torrance, CA) coupled to an amperometric detector (VT03; Antec, Leyden, The Netherlands). Basal values were averaged and used as a baseline to calculate percent change following drug injections. Area under the curve (AUC) values for drug treatments were calculated using values from 30 to $60 \mathrm{~min}$ post injection.

For confirmation of probe placement, mice were cervically dislocated and the brains were quickly removed and frozen on dry ice and stored at $-80^{\circ} \mathrm{C}$ until sectioning into $20 \mu \mathrm{m}$ coronal slices mounted directly onto slides. Sections were fixed for $1 \mathrm{~h}$ in $4 \%$ PFA, incubated for $1 \mathrm{~min}$ in cresyl violet $(0.3 \%)$, dehydrated in ethanol and coverslipped with Permount (Thermo Fisher Scientific, Waltham, MA). Images of the sections were scanned (Epson perfection V500) and inserted in Adobe Illustrator, and probe localization was determined and mapped onto a brain atlas.

\section{Behavioral Assays}

For the open field assay, mice were placed individually into plexiglass enclosures $43 \times 43 \mathrm{~cm}^{2}$ in size with $30.5 \mathrm{~cm}$ high walls (Med Associates), and allowed to explore undisturbed for $30 \mathrm{~min}$. Movements were recorded by beam breaks of two sets of 16 infrared photobeams. The center region was defined by the inner $21.2 \mathrm{~cm} \times 21.2 \mathrm{~cm}$ area. Total distance, percent center distance (the percent of the total distance that occurs in the center region), time in center, and center entries were analyzed by MED Associates software. The arena was lit at $\sim 400$ lux.

In the elevated plus maze, mice were videotaped while allowed to explore undisturbed for $5 \mathrm{~min}$. The maze had four arms $(7.6 \mathrm{~cm}$ wide by $28 \mathrm{~cm}$ long) that were $31 \mathrm{~cm}$ above the floor. The two opposing closed arms had $15 \mathrm{~cm}$ high walls, while the two opposing open arms had a $1 \mathrm{~cm}$ lip. Behavior was scored using TopScan (CleverSys, Reston, VA) for number of entries and time spent in each arm.

To assess fear behavior, mice were tested in a one-trial contextual fear conditioning paradigm. Specifically, mice were allowed to freely explore the fear conditioning boxes (Coulbourn Instruments) for $180 \mathrm{~s}$ with the lights and fan on. Following $180 \mathrm{~s}$, mice received a $1 \mathrm{~s}$ long $0.8 \mathrm{~mA}$ shock, and then remained in the box for an additional $20 \mathrm{~s}$ before they were removed to their home cage. The following day, mice were placed back into the same context for $180 \mathrm{~s}$. On the third day, mice were placed into the boxes with a significantly different context for $180 \mathrm{~s}$. This new context consisted of wood-shaving bedding (instead of metal bars), a lemon scent, with the lights off and a circular plastic enclosure obscuring the metal walls. Behavior was videotaped and the amount of time spent freezing was quantified using FreezeView software (Actimetrics, Wilmette, IL).

The forced swim test was conducted as previously described (Cryan et al, 2002) for $6 \mathrm{~min}$ on each of 2 days, with testing separated by $24-26 \mathrm{~h}$. The test was conducted in a 31 transparent plastic beaker $(22 \mathrm{~cm}$ height, $16.5 \mathrm{~cm}$ diameter) with a water depth of $15 \mathrm{~cm}$ and a water temperature of $26-27^{\circ} \mathrm{C}$. Cage-mates were tested simultaneously (3-5 mice at a time) in individual beakers separated by an opaque shield. Mobility was analyzed throughout both sessions using ViewPoint Life Sciences Software.

Sucrose preference was measured using two bottle preference tests. Mice were water restricted and trained to consume daily liquids within $30 \mathrm{~min}$ by gradually decreasing fluid availability over 4 days. Following training, mice were placed separately in cages daily for $30 \mathrm{~min}$ with access to two bottles for measurement of consumption. Bottles initially 

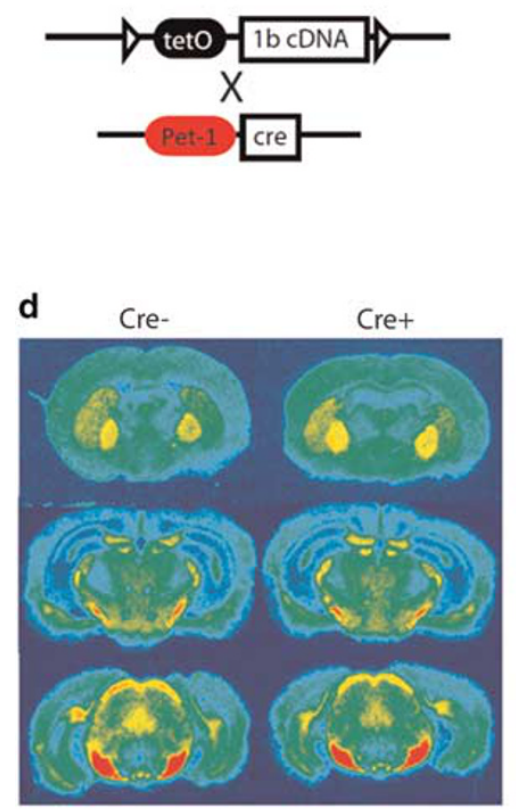

b

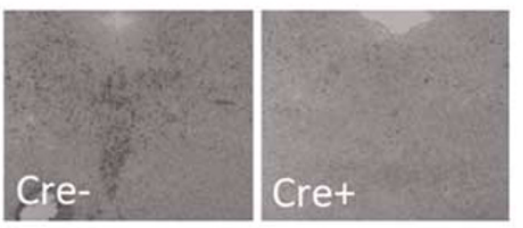

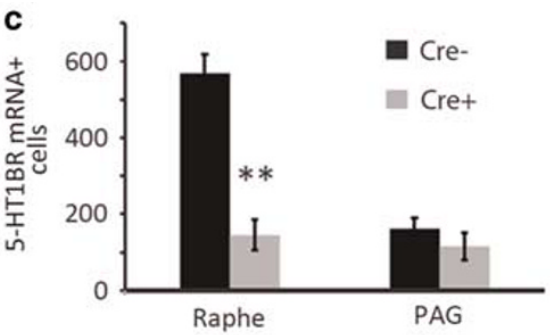

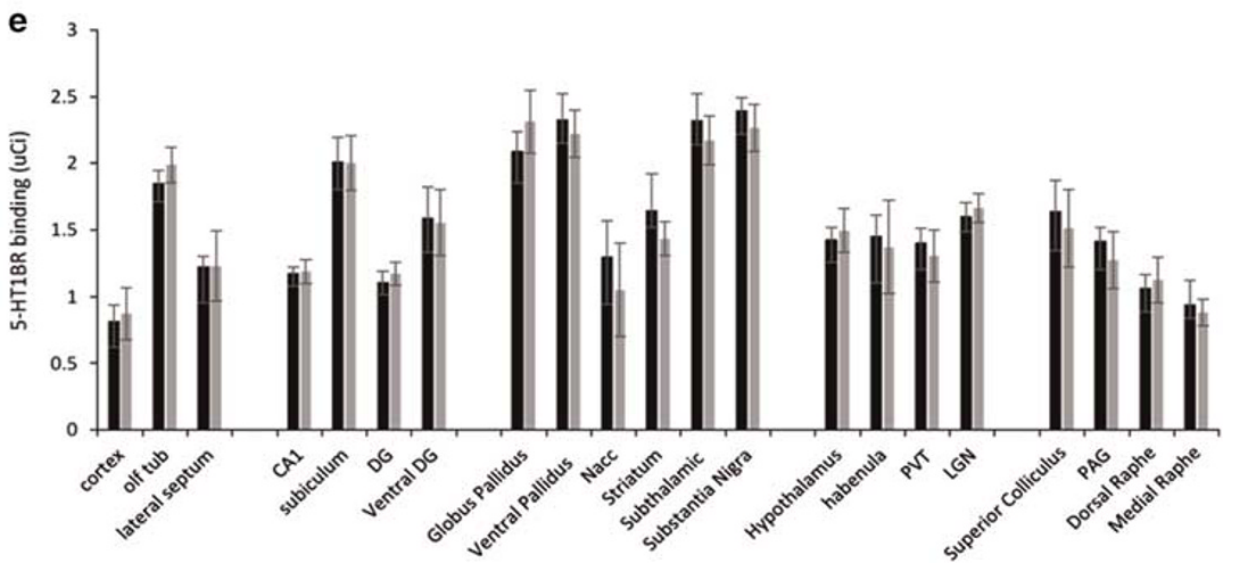

Figure I Serotonin IB (5-HT 1 ) autoreceptor knockout. (a) Schematic shows genetic cross used to yield autoreceptor knockdown. (b) Representative images of 5- $\mathrm{HT}_{1 \mathrm{~B}} \mathrm{R}$ mRNA in the raphe are shown for tetO IB::ePet-Cre+ mice and Cre - controls. (c) Counts of 5-HT/B $\mathrm{mRNA}+$ cells are shown in the raphe and periaqueductal gray (PAG) in Cre+ (gray) and Cre - control mice (black). (d) Representative autoradiographs from Cre - and Cre+ mice shown at three rostral-caudal levels (caudal to bregma: - I.0, - 2.5, and -4.0). (e) Quantification of 5-HTIB receptor autoradiography throughout the brain in Cre+ (gray) and Cre - controls (black). ${ }^{* *} p<0.01$.

contained water; then increasing concentrations of sucrose $(2,4,8$, and $16 \%)$ were presented. Before a choice test was performed at any concentration of sucrose, it was first presented in both bottles for 2 days. Then, on the four subsequent days, mice were presented with one bottle of water and one bottle of sucrose, switching the side of the bottle every day. Sucrose preference was calculated for each day by dividing the sucrose intake over the total fluid intake, corrected for individual body weight, and then averaged over the 4 days.

Novelty-suppressed feeding was measured following $18 \mathrm{~h}$ of food deprivation. Mice were placed into a novel arena consisting of a plastic box $(50 \times 50 \times 20 \mathrm{~cm})$. The floor was covered with approximately $2 \mathrm{~cm}$ of wood shaving bedding and a single pellet of food was placed on a white paper platform in the center of the arena, secured to the platform with a rubber band. Mice were placed individually in a corner of the arena and the latency to eat (defined as the mouse sitting on its haunches and biting the pellet with the use of forepaws) was recorded, with a maximum allowed latency of $300 \mathrm{~s}$.

\section{Statistical Analysis}

One-way analysis of variance (ANOVA) was used to assess the effect of genotype on behavior in the open field and elevated plus maze assays, and to test baseline differences for serotonin microdialysis. Repeated measures ANOVAs were used to examine the effect of genotype over brain regions for autoradiography, over days for forced swim and contextual fear tests, over time for microdialysis data, over sucrose concentrations for the sucrose preference test, and over SSRI treatment lengths for the novelty suppressed feeding test. Fisher's PLSD was used for post hoc testing when significant main effects were observed. StatView software was used for all analyses, and effects were considered statistically significant when $p$-values were less than 0.05 .

\section{RESULTS}

Floxed tetO1B mice were generated to enable tissue-specific knockdown of $5-\mathrm{HT}_{1 \mathrm{~B}} \mathrm{Rs}$ (Nautiyal et al, 2015). In the absence of Cre or tTS, mice have normal levels of $5-\mathrm{HT}_{1 \mathrm{~B}} \mathrm{R}$ as previously reported (Nautiyal et al, 2015). Crossing floxed tetO1B mice to a line expressing Cre under the Pet-1 promotor (Scott et al, 2005) allowed for 5- $\mathrm{HT}_{1 \mathrm{~B}}$ autoreceptor knockout (Figure 1a). There was reduced $5-\mathrm{HT}_{1 \mathrm{~B}}$ mRNA in the raphe of floxed tetO1B::ePet-Cre+ (referred to as ePet-Cre+) mice compared with floxed tetO1B::ePet-Cre (ePet-Cre - ) littermate controls (Figure 1b). Quantification revealed significantly fewer $5-\mathrm{HT}_{1 \mathrm{~B}}$ mRNA+ cells in the raphe of ePet-Cre - mice $\left(\mathrm{F}_{1,6}=44.3, p<0.01\right)$, but no significant effect in the periaqueductal gray, a nearby brain region that also expresses 5- $\mathrm{HT}_{1 \mathrm{~B}} \mathrm{R}$ mRNA (Figure 1c; $\left.\mathrm{F}_{1,6}=1.9, p>0.05\right)$. In contrast, receptor autoradiography for $5-\mathrm{HT}_{1 \mathrm{~B}} \mathrm{R}$ protein localization revealed no detectable differences in $5-\mathrm{HT}_{1 \mathrm{~B}} \mathrm{R}$ levels between ePet-Cre+ and control mice across all brain regions (Figure $1 \mathrm{~d}$ and e; $\mathrm{F}_{1,6}=0.9, p>0.05$ ), consistent with previous reports showing small, if any, 

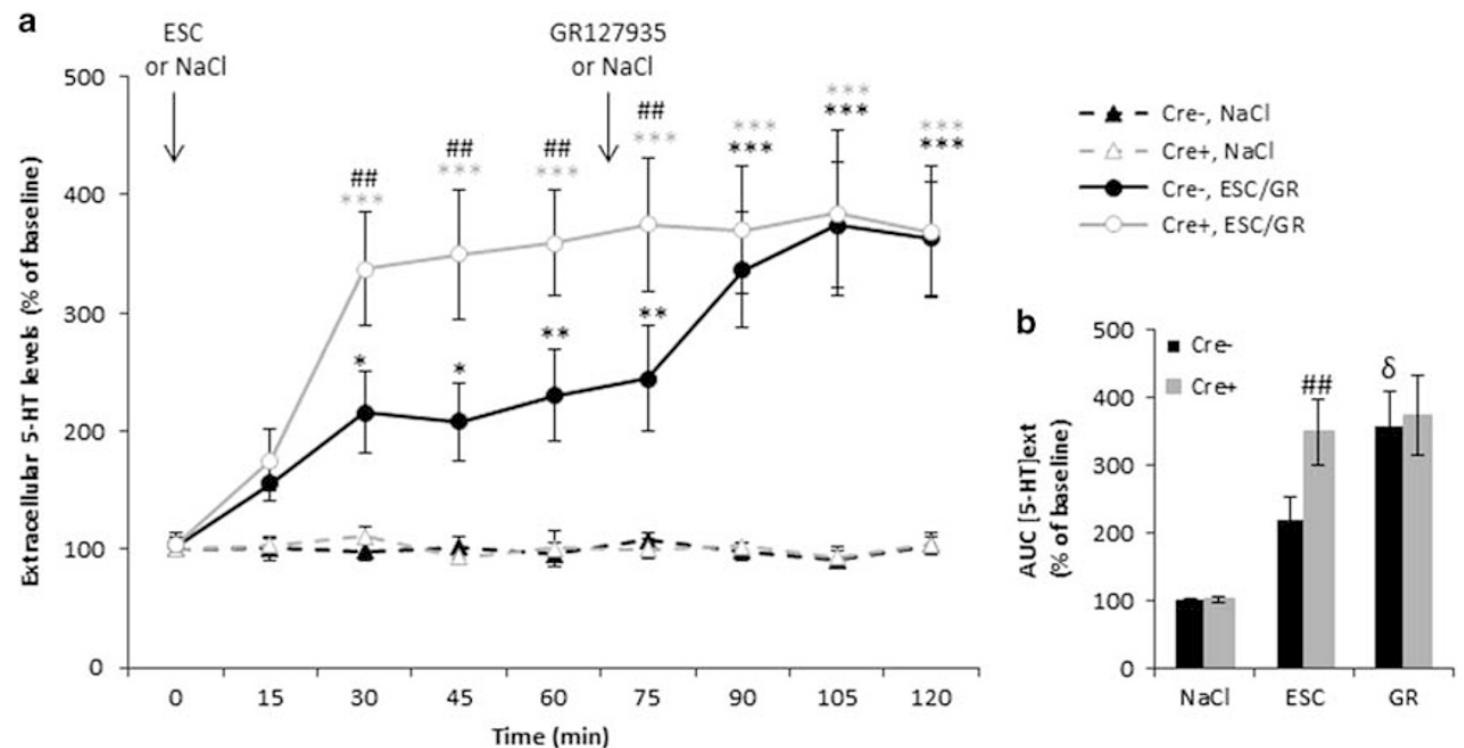

Figure 2 Microdialysis in serotonin IB $\left(5-\mathrm{HT}_{1 \mathrm{~B}}\right)$ autoreceptor knockout mice. (a) Serotonin levels, shown as percent of baseline over time, in the ventral hippocampus following injection of escitalopram (ESC) or saline control ( $\mathrm{NaCl}$ ), and then subsequent injection of 5-HT IBR antagonist GR I27935. * $p<0.05$; ${ }^{*} *{ }^{2}<0.01$; **** $p<0.00$ I for $\mathrm{NaCl}$ vs ESC or GR treatment. ${ }^{\# \#} p<0.0$ I for Cre - vs Cre+ comparison. (b) Area under the curve (AUC) values calculated for time periods 30-60 min following drug injection. ${ }^{\# \#} p<0.00$ I for Cre - vs Cre+ comparison; ${ }^{\delta} p<0.001$ for ESC vs GR treatment.

changes in receptor binding following lesions of serotonin cells (Compan et al, 1998; Offord et al, 1988; Pranzatelli et al, 1996). Additionally, to assess compensatory effects of $5-\mathrm{HT}_{1 \mathrm{~B}}$ autoreceptor knockout, receptor autoradiography for 5- $\mathrm{HT}_{1 \mathrm{~A}}$ and SERT was also performed (Supplementary Figure S1A and $\mathrm{C}$ ). There were no significant differences between ePetCre+ and ePet-Cre - mice in $5-\mathrm{HT}_{1 \mathrm{~A}} \mathrm{R}$ binding throughout the brain (Supplementary Figure S1B; $F_{1,8}=0.56, p>0.05$ ). There was a small, but significant increase in SERT binding in the ventral hippocampus of ePet-Cre+ mice (Supplementary Figure S1D; $\mathrm{F}_{1,6}=8.84, p<0.05$ ), consistent with the increase reported in the constitutive $5-\mathrm{HT}_{1 \mathrm{~B}} \mathrm{R} \mathrm{KO}$ mice (Ase et al, 2001).

We next measured the functional effect of $5-\mathrm{HT}_{1 \mathrm{~B}}$ autoreceptor knockout on extracellular serotonin levels in the ventral hippocampus using microdialysis (Figure 2). There were significant effects of $5-\mathrm{HT}_{1 \mathrm{~B}}$ autoreceptor knockout on 5-HT levels following SSRI treatment (Figure $2 \mathrm{a}$ and $\left.\mathrm{b} ; \mathrm{F}_{3,30}=6.5, p<0.01\right)$. Specifically, following peripheral injection of escitalopram, ePet-Cre+ mice had significantly higher levels of serotonin in the ventral hippocampus compared with ePet-Cre - littermate controls beginning $30 \mathrm{~min}$ post injection $\left(\mathrm{F}_{1,15}=5.0, p<0.05\right)$. Following a subsequent injection of GR 127935, a $5-\mathrm{HT}_{1 \mathrm{~B}} \mathrm{R}$ antagonist, ePet-Cre - mice showed elevations in 5-HT to match levels seen in ePet-Cre+ mice by 30 min post injection $\left(F_{1,15}=0.5, p>0.05\right)$. There was no effect of GR 127935 injection on 5 -HT levels in ePet-Cre+ mice $\left(\mathrm{F}_{1,14}=0.1\right.$, $p>0.05)$. There were also no detectable baseline differences between genotypes $\left(\mathrm{F}_{1,15}=0.1, p>0.05\right)$, as seen previously in male mice (Jones and Lucki, 2005). These data point to a functional role for $5-\mathrm{HT}_{1 \mathrm{~B}}$ autoreceptor in the regulation of hippocampal 5-HT levels.

Next, we assessed the effects of $5-\mathrm{HT}_{1 \mathrm{~B}}$ autoreceptor knockout on anxiety and depression-related behavior. An absence of $5-\mathrm{HT}_{1 \mathrm{~B}}$ autoreceptors in ePet-Cre+ mice resulted in decreased anxiety-like behavior. Specifically, in the open field test, ePet-Cre+ mice spent more time in the center of the arena compared to littermate ePet-Cre - mice (Figure 3a; $\left.\mathrm{F}_{1,23}=8.8, p<0.01\right)$. They were also more active overall as measured by distance travelled (Figure $3 \mathrm{~b} ; \mathrm{F}_{1,23}=5.8$, $p<0.05)$. Additionally, after controlling for the increased distance overall, ePet-Cre+ mice had an increased activity in the center of the arena compared with ePet-Cre - control mice ( $\%$ center distance; Figure $3 c ; \mathrm{F}_{1,23}=5.1, p<0.05$ ). There was also a trend towards increased number of entries into the center compared with littermate control ePet-Cre+ mice $\left(F_{1,23}=4.2, p=0.05\right)$. Consistent with the open field data, there was also a trend towards decreased anxiety-like behavior in ePet-Cre+ mice in the elevated plus maze, namely a trend towards more entries into the open arms in ePet-Cre+ mice compared with ePet-Cre- controls (Supplementary Figure S2A; $\mathrm{F}_{1,26}=3.0, p=0.095$ ). There were no significant effects on the time spent in the open arms or in the total number of entries into all arms (Supplementary Figure S2B and $\mathrm{C} ; \mathrm{F}_{1,26}<1.7, p>0.05$ ). Finally, given past evidence suggesting a role for $5-\mathrm{HT}_{1 \mathrm{~B}}$ autoreceptors in modulating learned fear behavior, we tested the response of ePet-Cre+ mice in a one trial contextual fear conditioning paradigm (Supplementary Figure S2D). While all mice showed increased freezing to the context following shock $\left(\mathrm{F}_{2,28}=41.3, p<0.001\right)$, we found no significant effects of genotype on freezing, suggesting no effect of life-long knockout of $5-\mathrm{HT}_{1 \mathrm{~B}}$ autoreceptors on context-based learned fear responses $\left(\mathrm{F}_{1,14}=0.1, p>0.05\right)$.

We also assessed the effects of the absence of $5-\mathrm{HT}_{1 \mathrm{~B}}$ autoreceptors on depressive-like behavior and found significant antidepressant-like effects in the ePet-Cre+ mice. In the forced swim test, they displayed increased mobility compared with littermate Cre- controls (Figure 4a; $\left.\mathrm{F}_{1,56}=6.02, p<0.05\right)$. Specifically, this effect was seen on day 2 with ePet-Cre+ mice $(p<0.01)$, mimicking an 

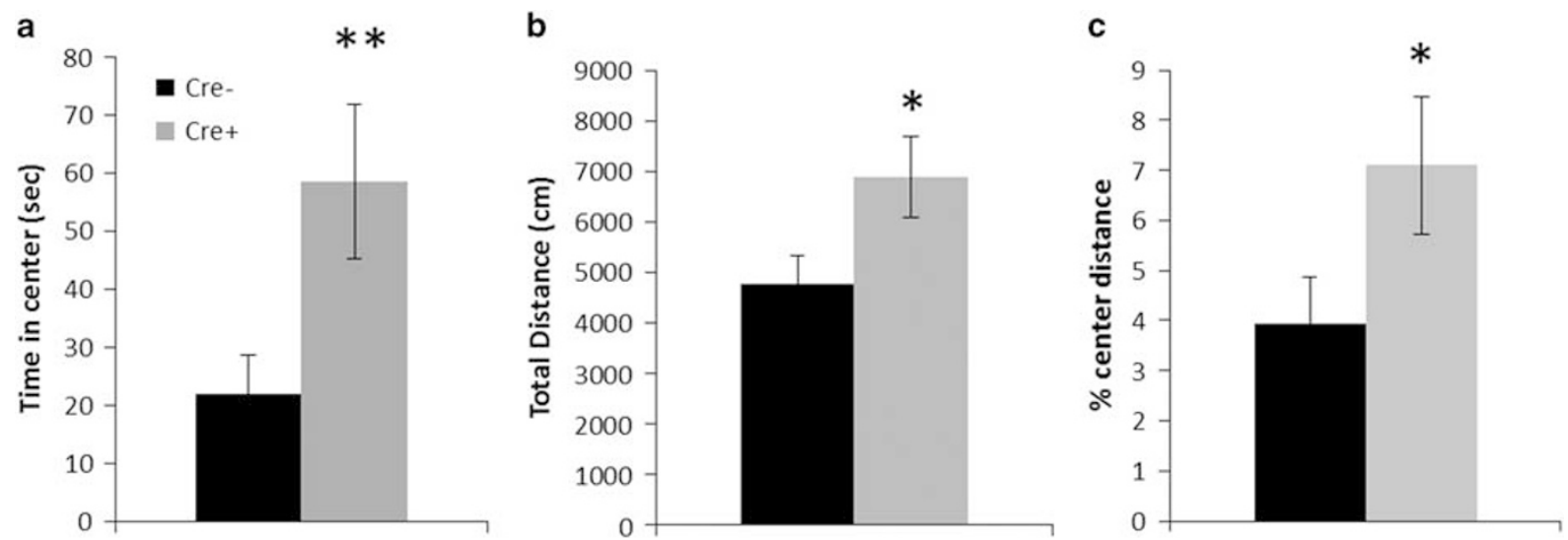

Figure 3 Open field behavior. Total time spent in the center of the arena (a), total distance travelled (b), and the percent of the total distance in the center (c) are shown in mice lacking serotonin IB (5-HT IB) autoreceptors (tetO IB::ePet-Cre+ mice; gray) and littermate Cre - controls (black); * $<<0.05$; *** $p<0.01$.
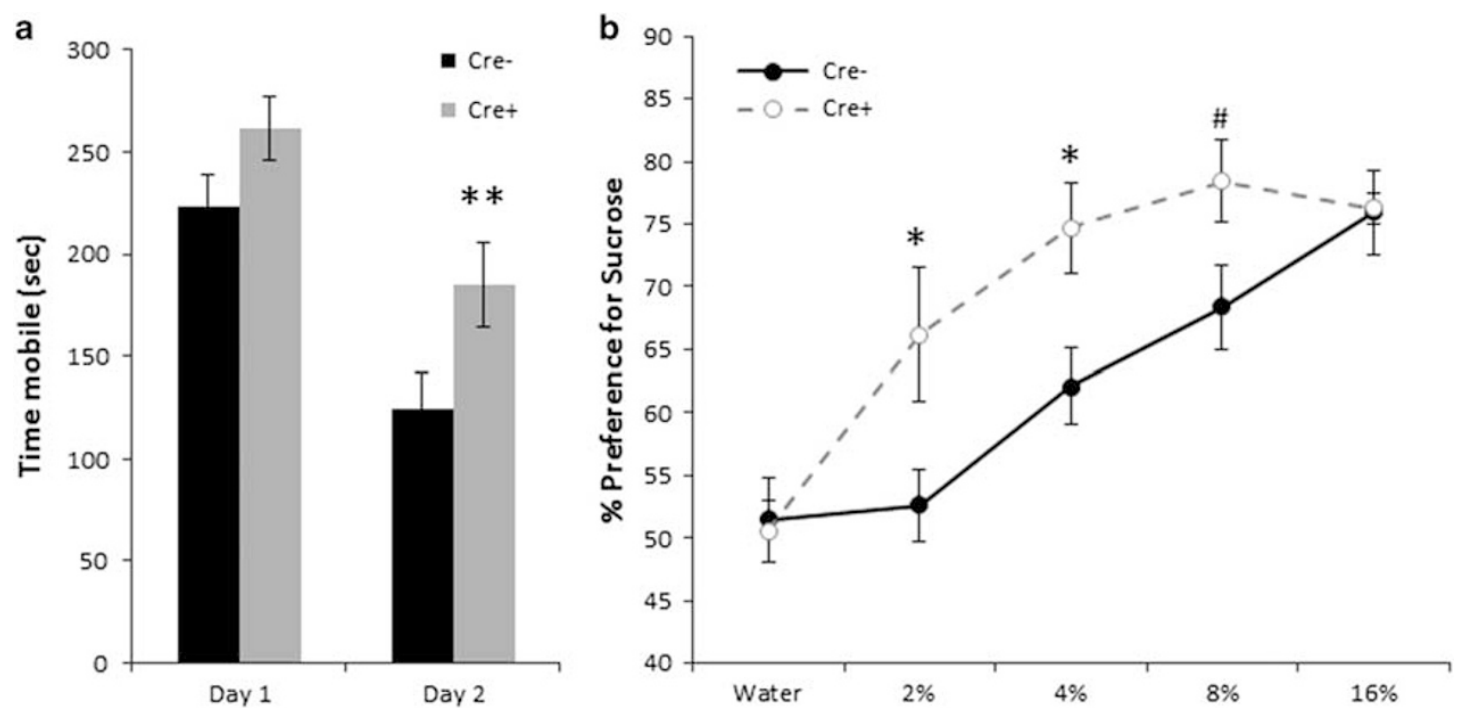

Figure 4 Depressive-like behaviours. (a) Mobility time in the forced swim test is shown for mice lacking 5-HT IB autoreceptors (tetO IB::ePet-Cre+; gray) and littermate Cre - (black) controls over 2 days. (b) Preference for sucrose at various concentrations in Cre+ mice and littermate Cre - controls. ${ }^{\#} p=0.05$; * $p<0.05$; *** $p<0.01$.

antidepressant-like response. Mice were also assessed in the sucrose preference test as a test of anhedonia or depressionrelated behavior, which is independent of activity levels. ePet-Cre+ mice showed increased preference for lower concentrations of sucrose compared with ePet-Cre - mice (Figure $4 \mathrm{~b} ; \mathrm{F}_{1,18}=11.8, p<0.01$ ). ePet-Cre+ mice preferred 2 and $4 \%$ sucrose significantly more than Cre - controls $(p<0.05)$. There was also a trend for increased preference at $8 \%$ in ePet-Cre+ mice $(p=0.05)$, with a significant increase in total consumption of the $8 \%$ sucrose solution $(p<0.05)$. There was no significant difference in body weights between the groups $(25.5 \pm 1.1 \mathrm{~g}$ for ePet-Cre - and $24.7 \pm 0.4 \mathrm{~g}$ for ePet-Cre+; $\left.F_{1,18}=1.3, p>0.05\right)$. There was also no effect on the amount of fluid consumption corrected for body weight $(0.081 \pm 0.004$ and $0.084 \pm 0.003 \mathrm{ml} / \mathrm{g}$ of body weight for ePet-Cre - and ePet-Cre+ mice, respectively; $F_{1,18}=0.2$, $p>0.05$ ), suggesting that the effect was not a result of change in thirst.
Given the increased levels of extracellular 5-HT following SSRI administration, we assessed the behavioral response to SSRI treatment (Supplementary Figure S3). Fluoxetine reduced the latency to eat in the novel arena $\left(\mathrm{F}_{2,28}=5.1\right.$, $p<0.05)$, regardless of genotype $\left(\mathrm{F}_{1,14}=0.01, p>0.05\right)$. More specifically, chronic (21 days), but not subchronic (10 days), treatment reduced the latency to eat from the pre-treatment baseline in both ePet-Cre - and ePet-Cre+ mice. The lack of any increased efficacy of SSRI treatment seen in ePet-Cre+ mice may have been due to limited group sizes, the remaining presence of $5-\mathrm{HT}_{1 \mathrm{~A}}$ autoreceptors, or differential circuitry underlying baseline depressive-like behavior compared with antidepressant responses.

Lastly, we addressed the potential developmental effect of $5-\mathrm{HT}_{1 \mathrm{~B}}$ autoreceptor knockdown by crossing floxed tetO1B mice to the Pet-tTS line. Floxed tetO1B::Pet-tTS+ (referred to as Pet-tTS+) mice lack autoreceptors during development, but not adulthood (Figure 5a). Pet-tTS+ mice showed 
a
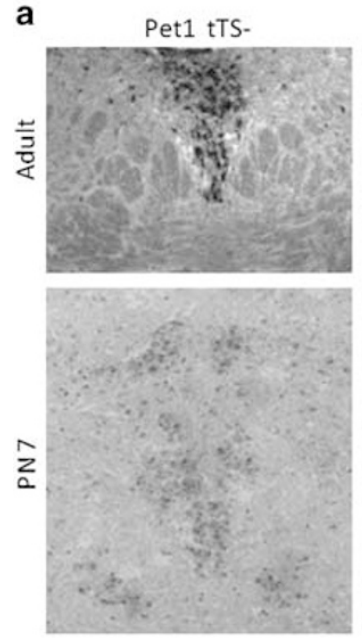

e

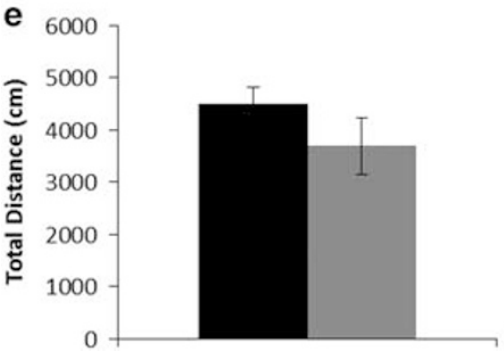

b

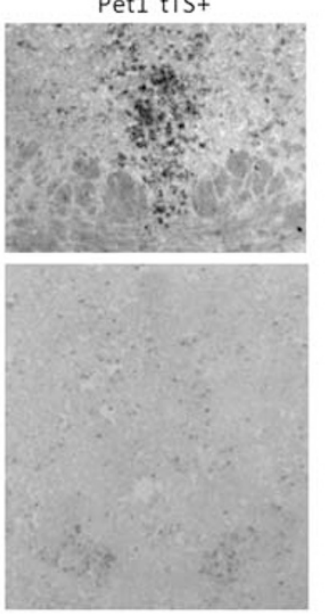

f
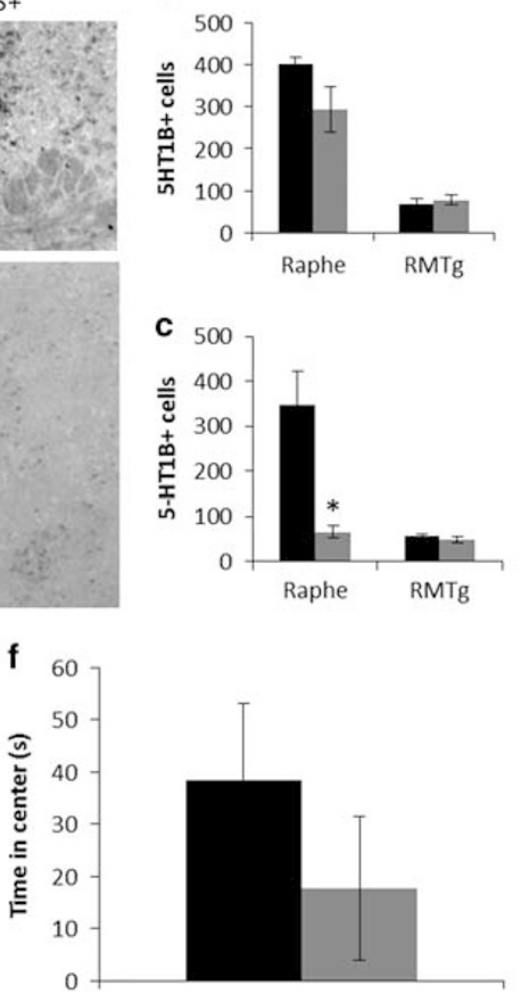

d

g

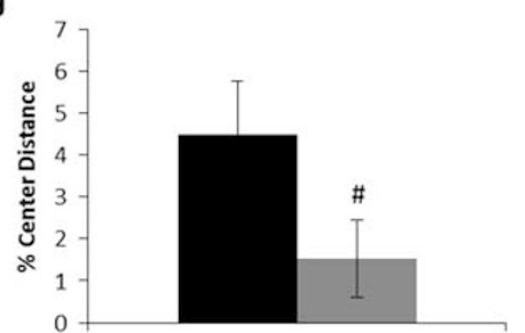

Figure 5 Developmental knockdown of 5-HTIB autoreceptors. (a) Representative images show 5-HTIBR mRNA in adult and PN7 mice that were floxed tetO IB:.PetI-tTS+ and littermate tTS - controls. Quantification of the number of 5-HT/B mRNA+ cells in the raphe and RMTg of adult (b) and PN7 (c) mice. (d) Mobility time in the forced swim test is shown for mice lacking 5-HTIB autoreceptors (tetO IB::ePet-Cre+; gray) and littermate Cre - (black) controls over 2 days. Open field behavior is shown as total distance travelled (e), total time spent in the center of the arena ( $f$ ), and the percent of the total distance in the center (g) for tetO I B.:Pet-tTS+ mice and littermate tTS - controls. * $p<0.0$ I; ${ }^{\#}<0.1$.

normal levels of $5-\mathrm{HT}_{1 \mathrm{~B}}$ mRNA in the raphe compared with littermate Pet-tTS - controls (Figure $5 b, \mathrm{~F}_{1,6}=1.3, p>0.05$ ). However, at postnatal day (PN) 7, mRNA in the raphe of Pet-tTS+ mice was significantly reduced compared with littermate Pet-tTS - controls (Figure $5 c ; \mathrm{F}_{1,6}=7.1, p<0.05$ ). There were no significant effects of genotype on the number of $5-\mathrm{HT}_{1 \mathrm{~B}} \mathrm{mRNA}+$ cells in the rostromedial tegmental area (RMTg) of either adult or PN7 mice $\left(\mathrm{F}_{1,6}=0.4, p>0.05\right.$ for adults; $F_{1,4}=0.3, p>0.05$ for PN7). Behaviorally, there were no significant differences between Pet-tTS+ mice and controls in the forced swim test or open field arena, two tests in which Pet-Cre+ mice differed significantly from controls. In the forced swim test, Pet-tTS mice showed no differences in time immobile compared with littermate controls (Figure 5d; $\mathrm{F}_{1,28}=0.03, p>0.05$ ). There were also no significant effects of developmental $5-\mathrm{HT}_{1 \mathrm{~B}}$ autoreceptor knockdown in the open field test measures of total distance (Figure 5e; $\mathrm{F}_{1,29}=1.06, p>0.05$ ), time in center (Figure 5f; $\mathrm{F}_{1,29}=1.66, p>0.05$ ), or \% center distance (Figure 5g; $\left.\mathrm{F}_{1,29}=3.35, p=0.08\right)$. In fact, there was a trend for increased anxiety-like behavior in the open field (center time and center distance), which is the opposite of what was found with the whole-life knockout of the autoreceptor. The lack of effects on behavioral tests in the developmental $5-\mathrm{HT}_{1 \mathrm{~B}}$ autoreceptor knockdown suggests that $5-\mathrm{HT}_{1 \mathrm{~B}}$ autoreceptors are involved in modulating anxiety and depression-like behavior primarily during adulthood.

\section{DISCUSSION}

The results presented show that an absence of $5-\mathrm{HT}_{1 \mathrm{~B}}$ autoreceptors throughout life results in an antidepressantlike phenotype-including decreased anxiety-like behavior in the open field and decreased depressive-like behavior in the forced swim and sucrose preference tests. Furthermore, we found increased extracellular serotonin levels in the ventral hippocampus of ePet-Cre+ mice in response to SSRI administration, suggesting a functional role for $5-\mathrm{HT}_{1 \mathrm{~B}}$ autoreceptors in the regulation of serotonin release in the hippocampus. These increases in serotonin levels and antidepressant-like phenotypes have been seen previously in the ubiquitous $5-\mathrm{HT}_{1 \mathrm{~B}} \mathrm{R} \mathrm{KO}$ (Bechtholt et al, 2008; Jones and Lucki, 2005; Knobelman et al, 2001; Mayorga et al, 2001), but importantly, our genetic model allowed the dissociation of the role of $5-\mathrm{HT}_{1 \mathrm{~B}}$ autoreceptors from heteroreceptors. This advancement is significant since pharmacological dissection via local infusion of antagonists or agonists is not possible given the terminal localization of $5-\mathrm{HT}_{1 \mathrm{~B}}$ autoreceptors throughout the brain (McDevitt and Neumaier, 2011). The identification of a population of $5-\mathrm{HT}_{1 \mathrm{~B}}$ receptors involved in modulating anxiety and depression is important given the diverse physiological effects which $5-\mathrm{HT}_{1 \mathrm{~B}} \mathrm{Rs}$ can cause depending on their localization. In fact, there is evidence which suggests an opposing role of $5-\mathrm{HT}_{1 \mathrm{~B}}$ heteroreceptors on anxiety and depressive behaviors. Namely, activation of $5-\mathrm{HT}_{1 \mathrm{~B}}$ 
heteroreceptors in a serotonin depletion model (to remove the contribution of autoreceptors) results in an antidepressant-like effect (Chenu et al, 2008). Additionally, reduced expression of $5-\mathrm{HT}_{1 \mathrm{~B}}$ heteroreceptors in the ventral striatum is associated with depression in humans (Murrough et al, $2011 b$ ). Finally, these ventral striatal $5-\mathrm{HT}_{1 \mathrm{~B}}$ heteroreceptors have been suggested to interact with p11 (a 5- $\mathrm{HT}_{1 \mathrm{~B}} \mathrm{R}$-binding protein) to affect depression-related behavior (Alexander et al, 2010; Svenningsson et al, 2006).

The increased extracellular serotonin levels in the hippocampus of ePet-Cre+ mice provide a possible mechanism of the behavioral effects seen between ePet-Cre - and ePet-Cre+ mice. Although we did not observe baseline differences in extracellular serotonin levels, consistent with previous reports in male mice (Jones and Lucki, 2005; Trillat et al, 1997), there may be differences between genotypes during specific behavioral tests resulting in higher serotonergic tone in the brains of Cre+ mice. In fact, increases in serotonin release have been seen in the brains of mice following $5-\mathrm{HT}_{1 \mathrm{~A}}$ autoreceptor knockdown with siRNA during tests of depressive behaviors, despite an absence in baseline differences (Ferres-Coy et al, 2013). Another potential mechanism through which $5-\mathrm{HT}_{1 \mathrm{~B}}$ autoreceptors could modulate anxiety and depression-like behavior is via effects on SERT function, given the impact of $5-\mathrm{HT}_{1 \mathrm{~B}}$ autoreceptors on the regulation of SERT activity and expression (Hagan et al, 2012; Montanez et al, 2014). While there were increases in levels of 5-HT in the hippocampus in ePet-Cre+ mice following inhibition of SERT function with SSRIs, preliminary studies showed no differential effect of SSRIs on behavior (Supplementary Figure S3). Lastly, another possibility includes a developmental contribution of $5-\mathrm{HT}_{1 \mathrm{~B}}$ autoreceptors to the maturation of neural circuits underlying these behaviors. However, our data showing a lack of significant effects of developmental knockdown in forced swim or open field behavioral tests (see Figure 5) suggest that the effect of $5-\mathrm{HT}_{1 \mathrm{~B}}$ autoreceptors on anxiety and depressive-like behavior is likely not mediated during early postnatal development.

Overall, our data are consistent with evidence suggesting a pro-depressive role for the activation of $5-\mathrm{HT}_{1 \mathrm{~B}}$ autoreceptors (Neumaier et al, 1997, 2002). However, there are also seemingly contradictory results. Specifically, studies report that increasing $5-\mathrm{HT}_{1 \mathrm{~B}}$ autoreceptor levels in the dorsal raphe using viral-mediated overexpression results in anxiolytic, antidepressive, and reduced fear behavior in rats (Clark et al, 2004; McDevitt et al, 2011). One difference between these results and our studies may be a result of cell-type specificity since the viral overexpression was not limited to serotonin cells. Specifically, GABAergic neurons in the raphe may express $5-\mathrm{HT}_{1 \mathrm{~B}}$ and overexpression in these cells may oppose the actions of $5-\mathrm{HT}_{1 \mathrm{~B}}$ autoreceptors (Weissbourd et al, 2014). In fact, the presence of remaining $5-\mathrm{HT}_{1 \mathrm{~B}}$ mRNA-containing cells in the raphe of ePet-Cre+ mice (see Figure 1) may correspond to these non-serotonin cells that express $5-\mathrm{HT}_{1 \mathrm{~B}}$. Another intricacy that has been previously suggested is that the role of $5-\mathrm{HT}_{1 \mathrm{~B}}$ autoreceptors may not be homogeneous throughout the raphe, but rather, receptors with different rostral-caudal localization within the dorsal raphe may have distinct effects (Clark et al, 2006; McDevitt et al, 2011). These location-specific manipulations are different from the genetic manipulation used here that results in knockout of $5-\mathrm{HT}_{1 \mathrm{~B}} \mathrm{R}$ throughout the dorsal and median raphe.

Interestingly, the role of $5-\mathrm{HT}_{1 \mathrm{~B}}$ autoreceptors seems divergent from that of the well-studied 5- $\mathrm{HT}_{1 \mathrm{~A}}$ autoreceptors (Garcia-Garcia et al, 2014). Our data suggest a substantially different role for the $5-\mathrm{HT}_{1 \mathrm{~A}}$ and $5-\mathrm{HT}_{1 \mathrm{~B}}$ autoreceptors in the modulation of anxiety and depression-like behavior. For example, whole-life knockout of 5- $\mathrm{HT}_{1 \mathrm{~A}}$ autoreceptors results in increased anxiety and no change in depressivelike behavior (Richardson-Jones et al, 2011), which contrasts with the decreased anxiety and depressive-like behavior that we report here with whole life knockout of $5-\mathrm{HT}_{1 \mathrm{~B}}$ autoreceptors. The anxiety phenotype in the $5-\mathrm{HT}_{1 \mathrm{~A}}$ autoreceptor knockout is likely due to the absence of the receptor during postnatal development (Donaldson et al, 2014), which is possibly related to the trend we observe in the developmental knockout of the $5-\mathrm{HT}_{1 \mathrm{~B}}$ autoreceptors. Interestingly, adult knockout of $5-\mathrm{HT}_{1 \mathrm{~A}}$ autoreceptors results in decreased depressive-like behaviors (Richardson-Jones et al, 2010), which is analogous to our findings in whole-life knockout of $5-\mathrm{HT}_{1 \mathrm{~B}}$ autoreceptors. These results are consistent with the fact that this antidepressant-like phenotype likely results from the absence of the $5-\mathrm{HT}_{1 \mathrm{~B}}$ autoreceptor during adulthood (since it is not observed in the developmental knockout). The disparities in effects of the $5-\mathrm{HT}_{1 \mathrm{~A}}$ and $5-\mathrm{HT}_{1 \mathrm{~B}}$ autoreceptors may be due to the differential subcellular localization, as $5-\mathrm{HT}_{1 \mathrm{~A}}$ is somatodendritic and $5-\mathrm{HT}_{1 \mathrm{~B}}$ is located at the presynaptic terminal (Ghavami et al, 1999). This differential localization may point to their roles in different circuits which contribute to depressive behavior (Knobelman et al, 2001). While the expression of $5-\mathrm{HT}_{1 \mathrm{~A}}$ and $5-\mathrm{HT}_{1 \mathrm{~B}}$ is overlapping in the raphe, small differences in the regional localization of the receptors within the raphe may also contribute to differences in receptor function (Clark et al, 2006). Finally, another possibility is that the $5-\mathrm{HT}_{1 \mathrm{~A}}$ and $5-\mathrm{HT}_{1 \mathrm{~B}}$ receptors may engage different non-canonical intracellular signaling cascades that lead to the different behavioral effects (Albert and Tiberi, 2001; Polter and Li, 2010).

While the mechanisms underlying the effects of these serotonin autoreceptors on anxiety and depressive behavior are unknown, these studies highlight the complexity of serotonergic modulation of affective behavior. Additional studies are needed to address the mechanisms of the effects of $5-\mathrm{HT}_{1 \mathrm{~B}}$ autoreceptors on depressive-like behaviors as well as interactions of sex with these effects (Jones and Lucki, 2005). Given the various underlying serotonergic mechanisms, it is interesting that a lack of $5-\mathrm{HT}_{1 \mathrm{~B}}$ autoreceptors was sufficient to generate antidepressant and anxiolytic responses. Taken together with studies showing dysregulation of $5-\mathrm{HT}_{1 \mathrm{~B}} \mathrm{Rs}$ in mood disorders in humans (Murrough et $a l, 2011 \mathrm{a}, \mathrm{b})$ and the potential involvement of $5-\mathrm{HT}_{1 \mathrm{~B}} \mathrm{Rs}$ in antidepressant responses (Tiger et al, 2014; Yamanaka et al, 2014), our results suggest the potential benefit of strategies aimed at targeting $5-\mathrm{HT}_{1 \mathrm{~B}}$ autoreceptor signaling for the treatment of anxiety and depression.

\section{FUNDING AND DISCLOSURE}

Funding was provided by NIH F32 MH100888 (to KMN), NIH K99 MH106731 (to KMN), Early Stage Investigator 
Award from the National Center for Responsible Gaming (to KMN), Sackler Institute Award (to KMN), NIH K08MH087718 (to SEA), Hope for Depression Research Foundation (to RH), NIH R01 MH083862 (to RH), and NIH R37 MH068542 (to $\mathrm{RH})$. $\mathrm{RH}$ receives compensation as a consultant from Lundbeck and Roche. DJD currently receives investigator-initiated research support from Lundbeck and served as a consultant in the areas of target identification and validation and new compound development to Lundbeck Inc., Roche, and Servier. The authors declare no potential conflict of interest.

\section{ACKNOWLEDGMENTS}

We thank Valerie Magalong, Salomon Muller, Jennifer Payne, and Anna Poszmik for technical assistance.

\section{REFERENCES}

Albert PR, Tiberi M (2001). Receptor signaling and structure: insights from serotonin-1 receptors. Trends Endocrinol Metab 12: 453-460. Alexander B, Warner-Schmidt J, Eriksson T, Tamminga C, Arango-Lievano M, Ghose S et al (2010). Reversal of depressed behaviors in mice by p11 gene therapy in the nucleus accumbens. Sci Transl Med 2: 54ra76.

Anthony JP, Sexton TJ, Neumaier JF (2000). Antidepressantinduced regulation of 5-HT(1b) mRNA in rat dorsal raphe nucleus reverses rapidly after drug discontinuation. J Neurosci Res 61: 82-87.

Ase AR, Reader TA, Hen R, Riad M, Descarries L (2001). Regional changes in density of serotonin transporter in the brain of 5-HT1A and 5-HT1B knockout mice, and of serotonin innervation in the 5-HT1B knockout. J Neurochem 78: 619-630.

Bechtholt AJ, Smith K, Gaughan S, Lucki I (2008). Sucrose intake and fasting glucose levels in 5-HT(1A) and 5- HT(1B) receptor mutant mice. Physiol Behav 93: 659-665.

Boschert U, Amara DA, Segu L, Hen R (1994). The mouse 5-hydroxytryptamine1B receptor is localized predominantly on axon terminals. Neuroscience 58: 167-182.

Chenu F, David DJ, Leroux-Nicollet I, Le Maitre E, Gardier AM, Bourin M (2008). Serotonin1B heteroreceptor activation induces an antidepressant-like effect in mice with an alteration of the serotonergic system. J Psychiatry Neurosci 33: 541-550.

Clark MS, McDevitt RA, Neumaier JF (2006). Quantitative mapping of tryptophan hydroxylase-2, 5-HT1A, 5-HT1B, and serotonin transporter expression across the anteroposterior axis of the rat dorsal and median raphe nuclei. J Comp Neurol 498: 611-623.

Clark MS, Sexton TJ, McClain M, Root D, Kohen R, Neumaier JF (2002). Overexpression of 5-HT1B receptor in dorsal raphe nucleus using herpes simplex virus gene transfer increases anxiety behavior after inescapable stress. J Neurosci 22: 4550-4562.

Clark MS, Vincow ES, Sexton TJ, Neumaier JF (2004). Increased expression of 5-HT1B receptor in dorsal raphe nucleus decreases fear-potentiated startle in a stress dependent manner. Brain Res 1007: 86-97.

Compan V, Segu L, Buhot MC, Daszuta A (1998). Selective increases in serotonin $5-\mathrm{HT} 1 \mathrm{~B} / 1 \mathrm{D}$ and $5-\mathrm{HT} 2 \mathrm{~A} / 2 \mathrm{C}$ binding sites in adult rat basal ganglia following lesions of serotonergic neurons. Brain Res 793: 103-111.

Cryan JF, Markou A, Lucki I (2002). Assessing antidepressant activity in rodents: recent developments and future needs. Trends Pharmacol Sci 23: 238-245.

Davidson C, Stamford JA (2000). Effect of chronic paroxetine treatment on 5-HT1B and 5-HT1D autoreceptors in rat dorsal raphe nucleus. Neurochem Int 36: 91-96.

Donaldson ZR, Piel DA, Santos TL, Richardson-Jones J, Leonardo ED, Beck SG et al (2014). Developmental effects of serotonin 1A autoreceptors on anxiety and social behavior. Neuropsychopharmacology 39: 291-302.

Ferres-Coy A, Santana N, Castane A, Cortes R, Carmona MC, Toth M et al (2013). Acute 5-HT(1)A autoreceptor knockdown increases antidepressant responses and serotonin release in stressful conditions. Psychopharmacology 225: 61-74.

Garcia-Garcia AL, Newman-Tancredi A, Leonardo ED (2014). 5-HT(1A) [corrected] receptors in mood and anxiety: recent insights into autoreceptor versus heteroreceptor function. Psychopharmacology 231: 623-636.

Gardier AM, David DJ, Jego G, Przybylski C, Jacquot C, Durier S et al (2003). Effects of chronic paroxetine treatment on dialysate serotonin in 5-HT1B receptor knockout mice. J Neurochem 86: 13-24.

Ghavami A, Stark KL, Jareb M, Ramboz S, Segu L, Hen R (1999). Differential addressing of 5-HT1A and 5-HT1B receptors in epithelial cells and neurons. J Cell Sci 112: 967-976.

Hagan CE, McDevitt RA, Liu Y, Furay AR, Neumaier JF (2012). $5-\mathrm{HT}(1 \mathrm{~B})$ autoreceptor regulation of serotonin transporter activity in synaptosomes. Synapse 66: 1024-1034.

Hjorth S, Suchowski CS, Galloway MP (1995). Evidence for 5-HT autoreceptor-mediated, nerve impulse-independent, control of 5-HT synthesis in the rat brain. Synapse 19: 170-176.

Jones MD, Lucki I (2005). Sex differences in the regulation of serotonergic transmission and behavior in 5-HT receptor knockout mice. Neuropsychopharmacology 30: 1039-1047.

Knobelman DA, Hen R, Lucki I (2001). Genetic regulation of extracellular serotonin by 5-hydroxytryptamine(1A) and 5-hydroxytryptamine(1B) autoreceptors in different brain regions of the mouse. J Pharmacol Exp Ther 298: 1083-1091.

Lucki I (1998). The spectrum of behaviors influenced by serotonin. Biol Psychiatry 44: 151-162.

Malagie I, Trillat AC, Bourin M, Jacquot C, Hen R, Gardier AM (2001). 5-HT1B autoreceptors limit the effects of selective serotonin re-uptake inhibitors in mouse hippocampus and frontal cortex. J Neurochem 76: 865-871.

Mayorga AJ, Dalvi A, Page ME, Zimov-Levinson S, Hen R, Lucki I (2001). Antidepressant-like behavioral effects in 5-hydroxytryptamine(1A) and 5-hydroxytryptamine(1B) receptor mutant mice. J Pharmacol Exp Ther 298: 1101-1107.

McDevitt RA, Hiroi R, Mackenzie SM, Robin NC, Cohn A, Kim JJ et al (2011). Serotonin 1B autoreceptors originating in the caudal dorsal raphe nucleus reduce expression of fear and depressionlike behavior. Biol Psychiatry 69: 780-787.

McDevitt RA, Neumaier JF (2011). Regulation of dorsal raphe nucleus function by serotonin autoreceptors: a behavioral perspective. J Chem Neuroanat 41: 234-246.

Mizutani H, Hori T, Takahashi T (2006). 5-HT1B receptormediated presynaptic inhibition at the calyx of held of immature rats. Eur J Neurosci 24: 1946-1954.

Montanez S, Munn JL, Owens WA, Horton RE, Daws LC (2014). 5 -HT1B receptor modulation of the serotonin transporter in vivo: studies using KO mice. Neurochem Int 73: 127-131.

Murrough JW, Czermak C, Henry S, Nabulsi N, Gallezot JD, Gueorguieva R et al (2011a). The effect of early trauma exposure on serotonin type $1 \mathrm{~B}$ receptor expression revealed by reduced selective radioligand binding. Arch Gen Psychiatry 68: 892-900.

Murrough JW, Henry S, Hu J, Gallezot JD, Planeta-Wilson B, Neumaier JF et al (2011b). Reduced ventral striatal/ventral pallidal serotonin1B receptor binding potential in major depressive disorder. Psychopharmacology 213: 547-553.

Nautiyal KM, Tanaka KF, Barr MM, Tritschler L, Le Dantec Y, David DJ et al (2015). Distinct circuits underlie the effects of 5 -HT1B receptors on aggression and impulsivity. Neuron 86: 813-826.

Neumaier JF, Edwards E, Plotsky PM (2002). 5-HT(1B) mrna regulation in two animal models of altered stress reactivity. Biol Psychiatry 51: 902-908. 
Neumaier JF, Petty F, Kramer GL, Szot P, Hamblin MW (1997). Learned helplessness increases 5-hydroxytryptamine1B receptor mRNA levels in the rat dorsal raphe nucleus. Biol Psychiatry 41: 668-674.

Neumaier JF, Root DC, Hamblin MW (1996). Chronic fluoxetine reduces serotonin transporter mRNA and 5-HT1B mRNA in a sequential manner in the rat dorsal raphe nucleus. Neuropsychopharmacology 15: 515-522.

Nguyen HT, Guiard BP, Bacq A, David DJ, David I, Quesseveur G et al (2013). Blockade of the high-affinity noradrenaline transporter (NET) by the selective 5-HT reuptake inhibitor escitalopram: an in vivo microdialysis study in mice. $\mathrm{Br} J$ Pharmacol 168: 103-116.

Offord SJ, Ordway GA, Frazer A (1988). Application of [125I] iodocyanopindolol to measure 5-hydroxytryptamine1B receptors in the brain of the rat. J Pharmacol Exp Ther 244: 144-153.

Paxinos G, Franklin KBJ. The mouse brain in stereotaxic coordinates, 2nd edn. Academic Press: San Diego, 2001.

Polter AM, Li X (2010). 5-HT1A receptor-regulated signal transduction pathways in brain. Cell Signal 22: 1406-1412.

Pranzatelli MR, Durkin MM, Farmer M (1996). Plastic responses of neonatal 5-hydroxytryptamine1B receptors to 5,7-dihydroxytryptamine lesions mapped by quantitative autoradiography. Int J Dev Neurosci 14: 621-629.

Ressler KJ, Nemeroff CB (2000). Role of serotonergic and noradrenergic systems in the pathophysiology of depression and anxiety disorders. Depress Anxiety 12 Suppl 1: 2-19.

Richardson-Jones JW, Craige CP, Guiard BP, Stephen A, Metzger KL, Kung HF et al (2010). 5-HT1A autoreceptor levels determine vulnerability to stress and response to antidepressants. Neuron 65: 40-52.

Richardson-Jones JW, Craige CP, Nguyen TH, Kung HF, Gardier AM, Dranovsky A et al (2011). Serotonin-1A autoreceptors are necessary and sufficient for the normal formation of circuits underlying innate anxiety. J Neurosci 31: 6008-6018.
Sari Y (2004). Serotonin1B receptors: from protein to physiological function and behavior. Neurosci Biobehav Rev 28: 565-582.

Saudou F, Amara DA, Dierich A, LeMeur M, Ramboz S, Segu L et al (1994). Enhanced aggressive behavior in mice lacking 5-HT1B receptor. Science 265: 1875-1878.

Scott MM, Wylie CJ, Lerch JK, Murphy R, Lobur K, Herlitze S et al (2005). A genetic approach to access serotonin neurons for in vivo and in vitro studies. Proc Natl Acad Sci USA 102: 16472-16477.

Stamford JA, Davidson C, McLaughlin DP, Hopwood SE (2000). Control of dorsal raphe 5-HT function by multiple 5-HT(1) autoreceptors: parallel purposes or pointless plurality? Trends Neurosci 23: 459-465.

Svenningsson P, Chergui K, Rachleff I, Flajolet M, Zhang X, El Yacoubi $M$ et al (2006). Alterations in 5-HT1B receptor function by p11 in depression-like states. Science 311: 77-80.

Tanaka KF, Samuels BA, Hen R (2012). Serotonin receptor expression along the dorsal-ventral axis of mouse hippocampus. Philos Trans R Soc Lond B Biol Sci 367: 2395-2401.

Tiger M, Ruck C, Forsberg A, Varrone A, Lindefors N, Halldin C et al (2014). Reduced 5-HT(1B) receptor binding in the dorsal brain stem after cognitive behavioural therapy of major depressive disorder. Psychiatry Res 223: 164-170.

Trillat AC, Malagie I, Scearce K, Pons D, Anmella MC, Jacquot C et al (1997). Regulation of serotonin release in the frontal cortex and ventral hippocampus of homozygous mice lacking 5-HT1B receptors: in vivo microdialysis studies. J Neurochem 69: 2019-2025.

Weissbourd B, Ren J, DeLoach KE, Guenthner CJ, Miyamichi K, Luo L (2014). Presynaptic partners of dorsal raphe serotonergic and GABAergic neurons. Neuron 83: 645-662.

Yamanaka H, Yokoyama C, Mizuma H, Kurai S, Finnema SJ, Halldin C et al (2014). A possible mechanism of the nucleus accumbens and ventral pallidum 5-HT1B receptors underlying the antidepressant action of ketamine: a PET study with macaques. Transl Psychiatry 4: e342.

Supplementary Information accompanies the paper on the Neuropsychopharmacology website (http://www.nature.com/npp) 